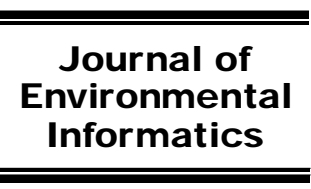

www.iseis.org/jei

\title{
Changes in Runoff and Sediment Yield along the Yellow River during the Period from 1950 to 2006
}

\author{
C. Liu $^{1}$, J. Sui ${ }^{2, *}$, and Z.Y. Wang ${ }^{3}$ \\ ${ }^{1}$ International Research and Training Center on Erosion and Sedimentation (IRTCES), Beijing 100044, China \\ ${ }^{2}$ Environmental Engineering, University of Northern British Columbia, Prince George, BC V2N 4Z9, Canada \\ ${ }^{3}$ Department of Hydraulic Engineering, Tsinghua University and IRTCES, Beijing 100044, China
}

Received 4 November 2007; revised 19 August 2008; accepted 10 September 2008; published online 1 December 2008

\begin{abstract}
In this paper, the changes in runoff and sediment yield have been assessed by using long-term observation data from 9 gauging stations on the Yellow River and 12 climate stations in the Yellow River watershed in China. It was observed that the annual precipitation depth at 3 climate stations in the headwater region of the Yellow River has an upward trend. However, in the lower section of the Upper Reach sub-watershed of the Yellow River, the annual precipitation depth has a slightly downward trend. In the Middle Reach sub-watershed, annual precipitation depth has a clear downward tendency. In the Lower Reach sub-watershed of the Yellow River, annual precipitation depth has a slightly upward tendency. Results indicate that, both annual sediment yield and annual runoff depth have a tendency of reduction in the past half century. The annual sediment yield in the Middle Reach is extremely high, with a long-term annual sediment yield of $1543.65 \mathrm{t} / \mathrm{km}^{2}$ at the Longmen station and $1631.39 \mathrm{t} / \mathrm{km}^{2}$ at the Tongguan station. In the Lower Reach, both annual runoff depth and sediment yield have a clearly downward trend. However, the long-term average annual sediment yield in the Lower Reach varies from 1035 to $1330 \mathrm{t} / \mathrm{km}^{2}$ which is still extremely high but less than those at gauging stations on the Middle Reach. The average annual sediment yield decreased significantly in recent 10 years. Examplewise, for the Yellow River at Lijin Station, the average runoff depth of the recent 10 years is only 1/3 of the long-term average value, and the average annual sediment yield of the recent 10 years is only $1 / 4$ of the long-term average value. Additionally, the impacts of human activities on both runoff depth and sediment yield have been discussed.
\end{abstract}

Keywords: grain size, Loess Plateau, runoff depth, sediment concentration, sediment yield, Yellow River

\section{Introduction}

Soil erosion is a worldwide problem that threatens an important and non-renewable resource - farmland. Soil erosion involves the detachment and movement of soil particles by both wind and water, but the latter is more significant. The soil erosion process can be accelerated by human activity, such as the removal of surface vegetation, forest harvesting, rangeland grazing, surface mining, and urbanization. Tillage implements, forest harvesting equipment, mining activities, and construction equipment all disturb the soil structure, which can also reduce the soil's resistance to detachment. In addition to removing a valuable resource, soil erosion leads to increased sediment input to nearby rivers, and thus deposition in the river system including reservoirs.

Sediment transport in rivers is particularly important for the global geochemical cycle and the transport of organic carbon from the land to the oceans by rivers (Ludwig et al., 1996).

* Corresponding author. Tel.: +1 2509606399.

E-mail address: sui@unbc.ca (J. Sui).

ISSN: 1726-2135 print/1684-8799 online

(C) 2008 ISEIS All rights reserved. doi:10.3808/jei.200800131
Sediment transport in rivers depends on both sediment properties and hydraulic parameters. Particle shape affects the incipient motion of sediment (Wang and Dittrich, 1999) and hydraulic parameters, such as flow velocity, shear stress of riverbed and hydraulic slope, influence the sediment transport capacity and the river dynamics (Wang and Wu, 2001). Furthermore, land use and vegetation coverage may exert a significant influence on runoff and sediment yield (Lu and Huang, 2003; Sui et al., 2000 and 2005; Wang and Wang, 1999).

As pointed out by Walling (2003), the land-ocean transfer of sediment by rivers is a key component of the global denudation system and provides a general measure of the rate of denudation of the continent. With the growth of interest in global change, many researchers have attempted to assess the changes in runoff and sediment transport by rivers. Existing research results indicate that sediment transport by rivers has tended to decrease globally in recent years. Walling (2003, 2005) carried out extensive investigations to assess the changes in annual runoff and sediment loads measured at the most downstream gauging stations on 142 world rivers. He found that rivers with the increasing annual runoff, decreasing annual runoff and stable annual runoff accounted for 8.5, 22.5 and 69.0 of the total, respectively. In respect of sediment transport, rivers with increasing annual sediment transport modulus, a decreasing an- 
Table 1. Water Transfer Capacity and Consumption of the Yellow River Watershed from 1998 to $2005\left(10^{9} \mathrm{~m}^{3}\right)(\mathrm{YRCC}$ 1999-2006)

\begin{tabular}{|c|c|c|c|c|c|c|c|c|}
\hline & 1998 & 1999 & 2000 & 2001 & 2002 & 2003 & 2004 & 2005 \\
\hline Water transfer & 37.0 & 38.4 & 34.6 & 33.7 & 36.0 & 29.6 & 31.2 & 33.2 \\
\hline Water consumption & 22.7 & 29.9 & 27.2 & 26.5 & 28.6 & 24.3 & 24.9 & 26.8 \\
\hline
\end{tabular}

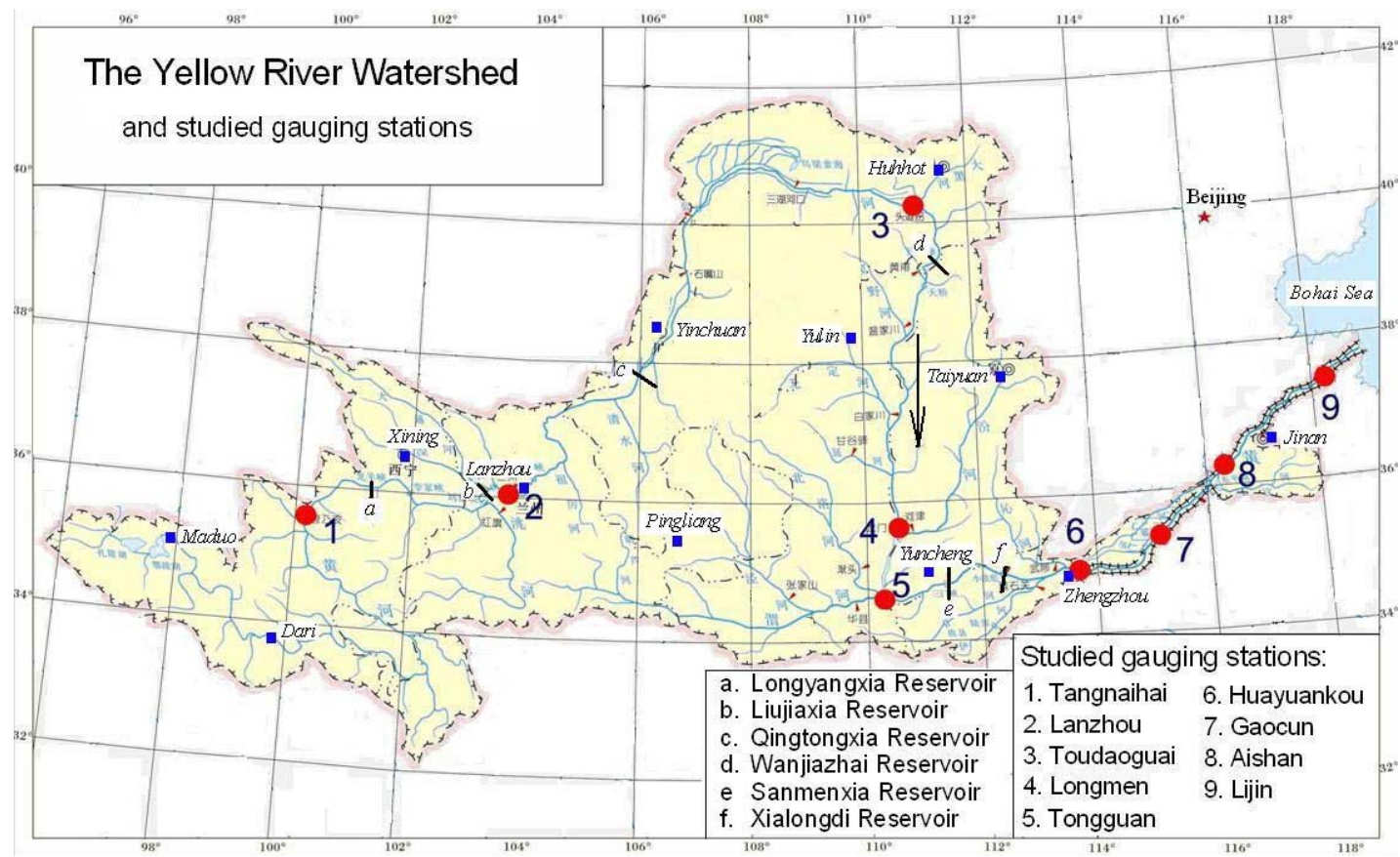

Figure 1. The studied gauging stations on the Yellow River.

nual sediment transport modulus and a stable annual sediment transport modulus accounted for 2.8, 47.9 and $49.3 \%$ of the total, respectively. Liu et al. (2008) assessed the changes in the annual runoff and sediment transport by using the long term observation data from 10 gauging stations on 10 large rivers across China from far north to far south. It is found that the annual sediment yield has generally had a decreasing trend in the past half century.

The Yellow River in China is known of its sediment problems. With booming economy and industrial development (such as hydropower development) as well as urbanization, some features of the watershed such as the percentage of vegetation (including secondary vegetation) may be dramatically changed. As a result, the rainfall-runoff process should be different from the original condition, and sediment transport by the river system should be affected.

Main methodologies used for water and soil conservation in the Yellow River watershed are contour cultivation, enlargement of the vegetated area, and construction of small sediment trapping dams in the easily eroded valleys. Before 1960, there was no hydropower development on the Yellow River. Additionally, very few water and soil conservation projects had been conducted in the Yellow River watershed before 1960. Started in the late 1960's, extensive water and soil conservation programs have been carried out in the Loess Plateau located in the Middle Reach sub-watershed of the Yellow River. Prior to 1959, as reported by $\mathrm{Gu}(1994,2002)$, the area with water and soil conservation programs was only $8,000 \mathrm{~km}^{2}$. However, the area with water and soil conservation programs increased to $15,800,36,000,79,200$, and $171,300 \mathrm{~km}^{2}$ by 1969,1979 , 1989 and 1998.

The Yellow River watershed is located in a semi-arid region. With the booming economy in this region, water consumption through irrigation, domestic and industrial uses increases significantly in the past two decades. In the Yellow River watershed, there are over 3,300 reservoirs, 17,000 hydraulic structures for water pumping and transferring (Xu, 2003). In 1950 's, the capacity of water pumping and transferring from the Yellow River and its branch rivers was about $12.5 \times 10^{9} \mathrm{~m}^{3}$. In 1970's, the capacity of water pumping and transferring exceeded $23.3 \times 10^{9} \mathrm{~m}^{3}$, and increased significantly in the past couple of years, as shown in Table 1 . As reported by YRCC (1999 to 2006), water consumption is highest along the river reach between Lanzhou and Todauguai, which accounts for $42.5 \%$ of the total respectively.

The purpose of this research work is to assess the changes of annual runoff and sediment yield in the Yellow River watershed by using long-term observation data released in China Gazette of River Sedimentation (MWR, 2002, 2003, 2004, 2005 and 2006). 
Table 2. Long-term and Recent 10 Year Average Annual Runoff Depths and Sediment Yields at 9 Gauging Stations on the Yellow River $^{*}$

\begin{tabular}{|c|c|c|c|c|c|c|c|c|c|}
\hline \multirow[t]{2}{*}{ Station } & \multicolumn{2}{|c|}{ Drainage } & \multirow[t]{2}{*}{ Data period } & \multicolumn{2}{|c|}{ Annual runoff depth } & \multirow{2}{*}{$\begin{array}{l}(\mathrm{mm}) \\
\mathrm{Q}_{10} / \mathrm{Q} \\
\end{array}$} & \multicolumn{2}{|c|}{ Annual sediment yield } & \multirow{2}{*}{$\begin{array}{rr}\mathrm{S} & \left(\mathrm{t} / \mathrm{km}^{2}\right) \\
& \mathrm{S}_{10} / \mathrm{S} \\
\end{array}$} \\
\hline & Location & Area $\left(\mathrm{km}^{2}\right)$ & & LTA-Q & RA-Q $Q_{10}$ & & LTA-S & RA-S 10 & \\
\hline Tangnaihai & & 121972 & $1950-2005$ & 163.95 & 137.96 & 0.84 & 103.19 & 85.15 & 0.83 \\
\hline Lanzhou & Upper reach & 222551 & 1950-2005 & 139.01 & 108.07 & 0.78 & 321.20 & 158.26 & 0.49 \\
\hline Toudaoguai & & 367898 & 1950-2005 & 59.34 & 35.10 & 0.59 & 294.26 & 82.82 & 0.28 \\
\hline Longmen & Middle reach & 497552 & 1950-2005 & 53.68 & 32.47 & 0.60 & 1543.65 & 612.48 & 0.40 \\
\hline Tongguan & Midale reach & 682141 & 1952-2005 & 51.29 & 29.79 & 0.58 & 1631.39 & 766.13 & 0.47 \\
\hline Huayuankou & & 730036 & 1950-2005 & 53.12 & 29.35 & 0.55 & 1331.93 & 427.97 & 0.32 \\
\hline Gaocun & J owor & 734146 & 1952-2005 & 49.13 & 25.16 & 0.51 & 1180.92 & 344.09 & 0.29 \\
\hline Aishan & Lower reach & 749136 & $1952-2005$ & 46.50 & 21.33 & 0.46 & 1112.75 & 332.33 & 0.30 \\
\hline Lijin & & 752032 & 1952-2005 & 41.66 & 14.41 & 0.35 & 1034.52 & 256.06 & 0.25 \\
\hline
\end{tabular}

*LTA: Long term Ave.; RA: Recent 10-yrs Ave.

\section{Studied Gauging Stations and Data Base}

As shown in Figure 1 and Table 2, data from following nine gauging stations on the Yellow River have been used to assess the changes in average annual runoff and sediment transport of the Yellow River: Tangnaihai, Lanzhou, Toudaoguai, Longmen, Tongguan, Huayuankou, Gaocun, Aishan and Lijin gauging stations. Data of all gauging stations released in the China Gazette of River Sedimentation have been used. All data series have a period of record more than 54 years. The drainage areas at the studied gauging stations ranges from 121,972 $\mathrm{km}^{2}$ (at the Tangnaihai station) to $752,032 \mathrm{~km}^{2}$ (at the Lijin station).

The Yellow River is well-known by its enormous amount of sediment it carries. The average annual sediment flux between 1952 and 2005 at the Lijin station on the Lower Reach of the Yellow River is $0.78 \times 10^{9} \mathrm{t}$ with an average annual sediment concentration of $24.8 \mathrm{~kg} / \mathrm{m}^{3}$ (MWR, 2005). The drainage area of the upstream sub-watershed of the Yellow River at the Lanzhou gauging station accounts for $30 \%$ of the total drainage area. However, 58\% of discharge water in the Yellow River comes from this region. The drainage area of the subwatershed of the Middle Reach of the Yellow River between the Hekouzhen (downstream of the Toudaoguai Station) and the Longmen station is $1.13 \times 10^{5} \mathrm{~km}^{2}$ which accounts only for $15 \%$ of the total drainage area. However, over $90 \%$ of total sediment is yielded in this region. The Huangfuchuan River which is the most important branch river to the Yellow River because of its high sediment concentration is located in this region (Sui et al., 2005). Started in the 1960's, some hydro dams have been built on the Yellow River. As a result, the runoff and sediment transport by the Yellow River have been changed.

Before assessing the changes in runoff at different gauging stations on the Yellow River, long-term annual precipitation depth at 12 climate stations in the Yellow River watershed have been investigated. Following 6 climate stations are located in the Upper Reach sub-watershed of the Yellow River: Maduo, Dari, Xining, Lanzhou, Yinchuan, and Huhhot stations. Following 4 climate stations are located in the Middle Reach sub-watershed: Pingliang, Yulin, Taiyuan and Yuncheng stations. Zhengzhou and Jinan stations are 2 climate stations lo- cated in the Lower Reach sub-watershed.

In this paper, the annual runoff depth in millimeter [annual average discharge per unit area $=Q \times 365 \times 24 \times 3600 /(1000$ $\times A$ ), where $Q=$ annual discharge in $\mathrm{m}^{3} / \mathrm{s}, A=$ drainage area in $\mathrm{km}^{2}$ ] and sediment yield (annual suspended sediment flux per unit area, $t / \mathrm{km}^{2}$ ) have been used to compare the changes in runoff and sediment at different locations along the Yellow River. To assess the changes in runoff and sediment flux for each river, trend analysis by using linear regression for runoff depth and sediment yield has been conducted. The dependence of the sediment yield on runoff depth has been explored for each gauging station. Additionally, the impacts of human activities on the changes in runoff and sediment yield have also been investigated.

\section{Results}

\subsection{Precipitation in the Yellow River Watershed}

Precipitation depth is one important factor affecting the magnitude of the runoff depth in a river system. The assessment results of long-term annual precipitation depth at 12 studied climate stations in the Yellow River watershed are shown in Table 3 and Figures 2a to 2d. It was observed that the annual precipitation depth at 3 climate stations (Maduo, Dari and Xining stations) in the headwater region of the Yellow River has an upward trend. This result confirms the finding of other researchers (Xu and Zhang 2006; Ye et al., 2004). However, in stations located in the lower section of the Upper Reach subwatershed of the Yellow River such as Lanzhou, Yinchuan, and Huhhot stations, the annual precipitation depth has a slightly downward trend. In the Middle Reach sub-watershed, as indicated by trend lines of annual precipitation depth at Pingliang, Yulin, Taiyuan and Yuncheng climate stations in Figure 2c, annual precipitation depth has a clear downward tendency. Geographically, the lower section of the Upper Reach sub-watershed of the Yellow River is also located in or close to the Loess Plateau. Thus, the annual precipitation depth at climate stations in this region has a similar tendency of decrease as that in the Middle Reach sub-watershed. In the Lower Reach sub-watershed of the Yellow River, as shown in Figure 2d, annual precipitation depth has a slightly upward tendency. 

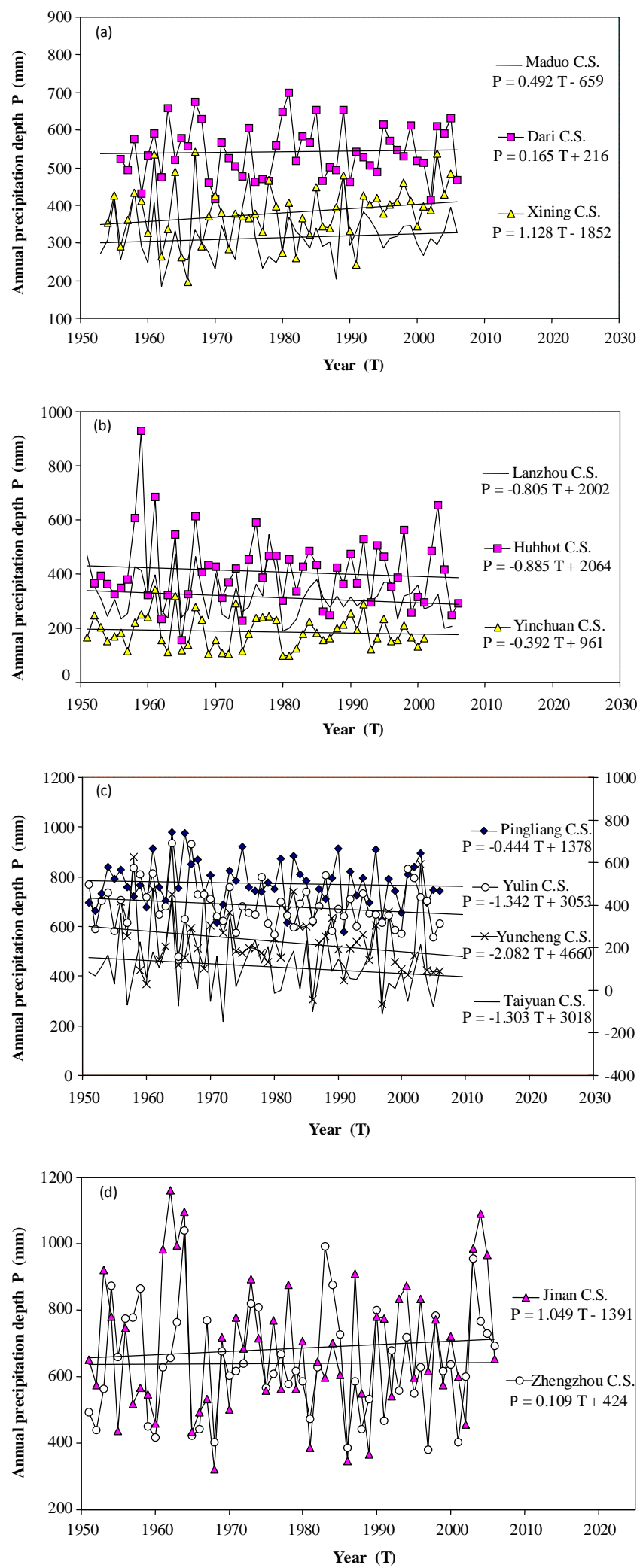

Figure 2. Changes in precipitation depth in the Yellow River watershed: a) upper reach - headwater region, b) upper reach - lower region, c) middle reach, and d) lower reach.
Table 3 also gives the ratios of the average precipitation depths in recent 10 years to those of long-term values for all 12 studied climate stations. It is found that in the headwater region and the Lower Reach sub-watershed of the Yellow River, the annual precipitation depth in recent 10 years has a tendency of increase. In the lower section of the Upper Reach subwatershed and the Middle Reach sub-watershed, the annual precipitation depth has a trend of decrease in recent 10 years.

\subsection{Some Major Changes of the Yellow River Watershed}

By 2005, 171 large reservoirs / hydropower stations have been built in the Yellow River watershed (MWR, 2006). As shown in Figures 3 and 4, followings are some major changes of the Yellow Rivers due to construction of reservoirs/hydropower stations which play a significant role on the changes in runoff and sediment transport:

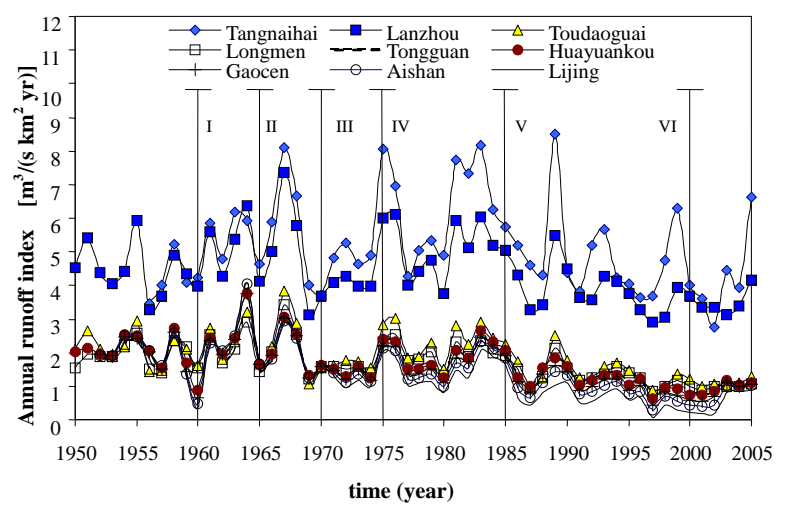

Figure 3. Changes in annual runoff depth of the Yellow River.

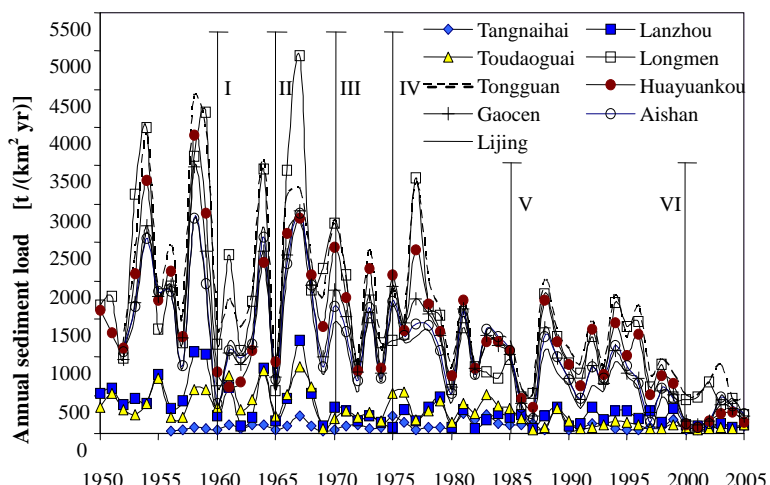

time (year)

Figure 4. Changes in annual sediment yield of the Yellow River.

1) From 1960 to 1964, the Sanmenxia reservoir (downstream of the Tongguan station) was built and in operation on the Yellow River. The total storage capacity and effective storage capacity of the Sanmenxia reservoir are $9.64 \times 10^{9} \mathrm{~m}^{3}$ and $6.04 \times 10^{9} \mathrm{~m}^{3}$, respectively. During water impoundment phase, a lot of sediment has been trapped in this reservoir in the first couple of years. 
Table 3. Long-term and Recent 10 year Average Annual Precipitation Depth at 12 Climate Stations in the Yellow River Watershed

\begin{tabular}{clcccc}
\hline Climate station & River Reach of the Yellow River & Data period & Long-term Ave. $\mathrm{P}_{\mathrm{L}}$ & Recent 10-yrs Ave. $\mathrm{P}_{10}$ & $\mathrm{P}_{10} / \mathrm{P}_{\mathrm{L}}$ \\
\hline Maduo & & $1953-2006$ & 314.10 & 323.57 & 1.03 \\
Dari & Upper Reach - headwater region & $1956-2006$ & 542.81 & 543.16 & 1.00 \\
Xining & & $1954-2005$ & 380.01 & 426.42 & 1.12 \\
Lanzhou & & $1951-2005$ & 313.84 & 289.46 & 0.92 \\
Yinchuan & Upper Reach - lower region & $1951-2006$ & 191.99 & 174.26 & 0.91 \\
Huhhot & & $1952-2006$ & 409.20 & 391.02 & 0.96 \\
Pingliang & & $1951-2006$ & 500.59 & 480.1 & 0.96 \\
Yulin & \multirow{2}{*}{ Middle Reach } & $1951-2006$ & 396.93 & 373.13 & 0.94 \\
Taiyuan & & $1951-2006$ & 439.01 & 370.94 & 0.84 \\
Yuncheng & & $1956-2006$ & 536.04 & 482.59 & 0.90 \\
Zhengzhou & Lower Reach & $1951-2006$ & 639.88 & 656.02 & 743.6 \\
Jinan & & $1951-2006$ & 684.27 & 7.03 & 1.09 \\
\hline
\end{tabular}
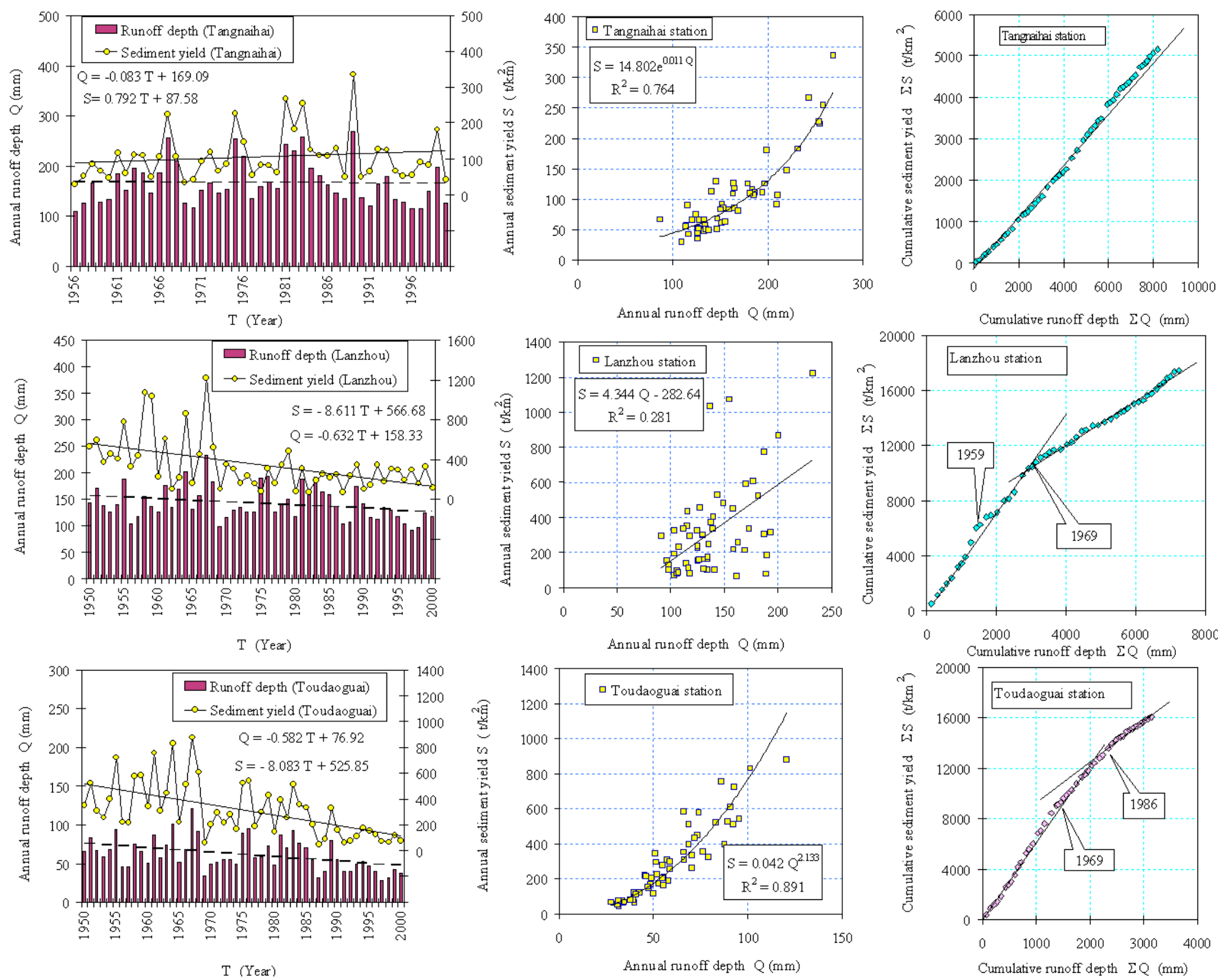

Figure 5. Changes in annual runoff depth and sediment yield of the upper reach of the Yellow River. 
2) From 1965 to 1973, the operation mode of the Sanmenxia Reservoir has been modified for flood detention and sediment flushing.

3) In 1968, the Liujiaxia reservoir / hydropower station (80 $\mathrm{km}$ upstream of the Lanzhou gaging station) started to impound water and generated power in 1969. The total storage capacity and effective storage capacity of the Liujiaxia reservoir are $5.70 \times 10^{9}$ and $4.15 \times 10^{9} \mathrm{~m}^{3}$, respectively.

4) Since 1974, the operation mode of the Sanmenxia reservoir has been modified to impound "clear water" during low flow season and flush "turbid water" during flood periods.

5) In 1986, the upstream Longyangxia reservoir was completed. The total storage capacity and effective storage capacity of the Longyangxia reservoir are $24.7 \times 10^{9}$ and $19.4 \times 10^{9} \mathrm{~m}^{3}$, respectively. Since 1986 , a combined operation of the Liujiaxia and Longyangxia reservoirs has been used for flood detention.

6) Since 2000, the Xiaolangdi reservoir (downstream of the Sanmenxia reservoir) was in operation. The total storage capacity and effective storage capacity of the Xiaolangdi reservoir are $12.65 \times 10^{9}$ and $5.10 \times 10^{9} \mathrm{~m}^{3}$, respectively.

\subsection{Changes in Runoff Depth and Sediment Yield in the Upper Reach}

Based on the assessments of the long-term discharge and sediment records of three gauging stations on the Upper Reach of the Yellow River, following results regarding the changes in runoff and sediment yield have been identified:

As shown in Figure 5, in the past half century, the annual runoff depth at the Tangnaihai station in the headwater region of the Yellow River watershed has a slightly upward trend. This means that the runoff depth in the headwater region has a tendency of increase over the past century. The slightly increase in annual precipitation depth in the headwater region of the Yellow River, especially in 1980's, should be responsible for this. The long-term average runoff depth at the Tangnaihai station is $163.95 \mathrm{~mm}$ which are very high comparing to those at other studied gaging stations on the Yellow River. In recent 10 years, average runoff depth at the Tangnaihai station decreases to $137.96 \mathrm{~mm}$. The annual runoff depth at the Tangnaihai station represents the flow under a natural condition of the headwater region of the Yellow River, since there have not been hydropower development and water transfer program in this region. The trend line of the annual sediment yield of the subwatershed of the Yellow River at the Tangnaihai station was quasi-stationary. The long-term average annual sediment yield at the Tangnaihai station is $103.19 \mathrm{t} / \mathrm{km}^{2}$ which is the lowest in sediment yield among 9 studied stations on the Yellow River, and decreased to $85.15 \mathrm{t} / \mathrm{km}^{2}$ in recent 10 years. The curve de- scribing the relationship between cumulative annual sediment yield and annual runoff depth also indicates this finding. The dependence of the annual sediment yield on annual runoff dep- th at the Tangnaihai station is strong.

The long-term average annual runoff depth at the Lan- zhou station is $139.01 \mathrm{~mm}$ which are very high comparing to the values at other stations on the Yellow River. In recent 10 years, average annual runoff depth at the Lanzhou station decreases to $108.07 \mathrm{~mm}$. As shown in Figures 6 and 7, the longterm average annual sediment yield of the sub-watershed of the Yellow River at the Lanzhou station is $321.20 \mathrm{t} / \mathrm{km}^{2}$ which is also very low comparing to the sediment yield at other 6 stations on the Middle and Lower reaches of Yellow River. In recent 10 years, the average annual sediment yield at the Lanzhou station decreased to $158.26 \mathrm{t} / \mathrm{km}^{2}$. The clear decrease in sediment transport in 1969, as shown in the cumulative sediment yield curve, indicates the accomplishment of the Liujiaxia reservoir in 1969, since the majority of sediment was trapped in this reservoir. The relationship between annual sediment yield and annual runoff depth at the Lanzhou station is very weak.

The Toudaoguai station is the last station on the Upper Reach of the Yellow River. As Figure 5 shown, both annual runoff depth and sediment yield of the sub-watershed of the Yellow River at the Toudaoguai station has a slightly downward trend with time. The long-term average annual runoff depth at the Toudaoguai station is only $59.34 \mathrm{~mm}$ which is much less than those at the Tangnaihai and Lanzhou stations, and decreases to $35.10 \mathrm{~mm}$ in recent 10 years. The long-term average annual sediment yield at the Toudaoguai station is $294.26 \mathrm{t} / \mathrm{km}^{2}$ which is also very low comparing to the annual sediment yield at other 6 stations on the Middle and Lower reaches, and decreased to $82.82 \mathrm{t} / \mathrm{km}^{2}$ in recent 10 years. From the cumulative annual sediment yield curve of the Toudaoguai station, it is observed that there are clearly decreases in sediment yield in 1969 and 1986. The decrease in sediment yield in 1969 was resulted from the installation of the upstream Liujiaxia reservoir. The soil and water conservation program started in the late 1970's should play an important role on the decrease in sediment yield in 1986. On the other side, increased water transfer capacity in the Inner Mongolia region also resulted in a decrease in annual runoff depth at the Toudaoguai station and thus the sediment yield, although the Upper Reach sub-watershed of the Yellow River experiences a slightly increase in annual precipitation depth. The upstream Longyangxia reservoir was completed in 1986. As a result, the annual runoff and sediment yield at the downstream Lanzhou station decreased in 1986. However, as shown in the cumulative sediment yield curve, no clearly change in annual sediment yield at the Toudaoguai station in 1986 has been identified. One can conclude that the installation of the upstream Longyangxia reservoir in 1986 was not a factor responsible for the changes in the sediment yield at the downstream Toudaoguai station. However, as shown in the cumulative sediment yield curve of the Toudaoguai station, clearly decreases in sediment yield experienced in 1988 and 1998 respectively. Increased water transfer capacity from the Yellow River in the Inner Mongolia region caused the decrease in the annual runoff depth and thus sediment yield. As reported by YRCC (1999), the water transfer capacity from the Yellow River upstream of the Lanzhou station in 1998 is $3.3 \times 10^{9} \mathrm{~m}^{3}$ which accounts of $9 \%$ of total water transfer capacity of $37.0 \times 10^{9} \mathrm{~m}^{3}$ from the Yellow River. The water transfer capacity from the Yellow River upstream 

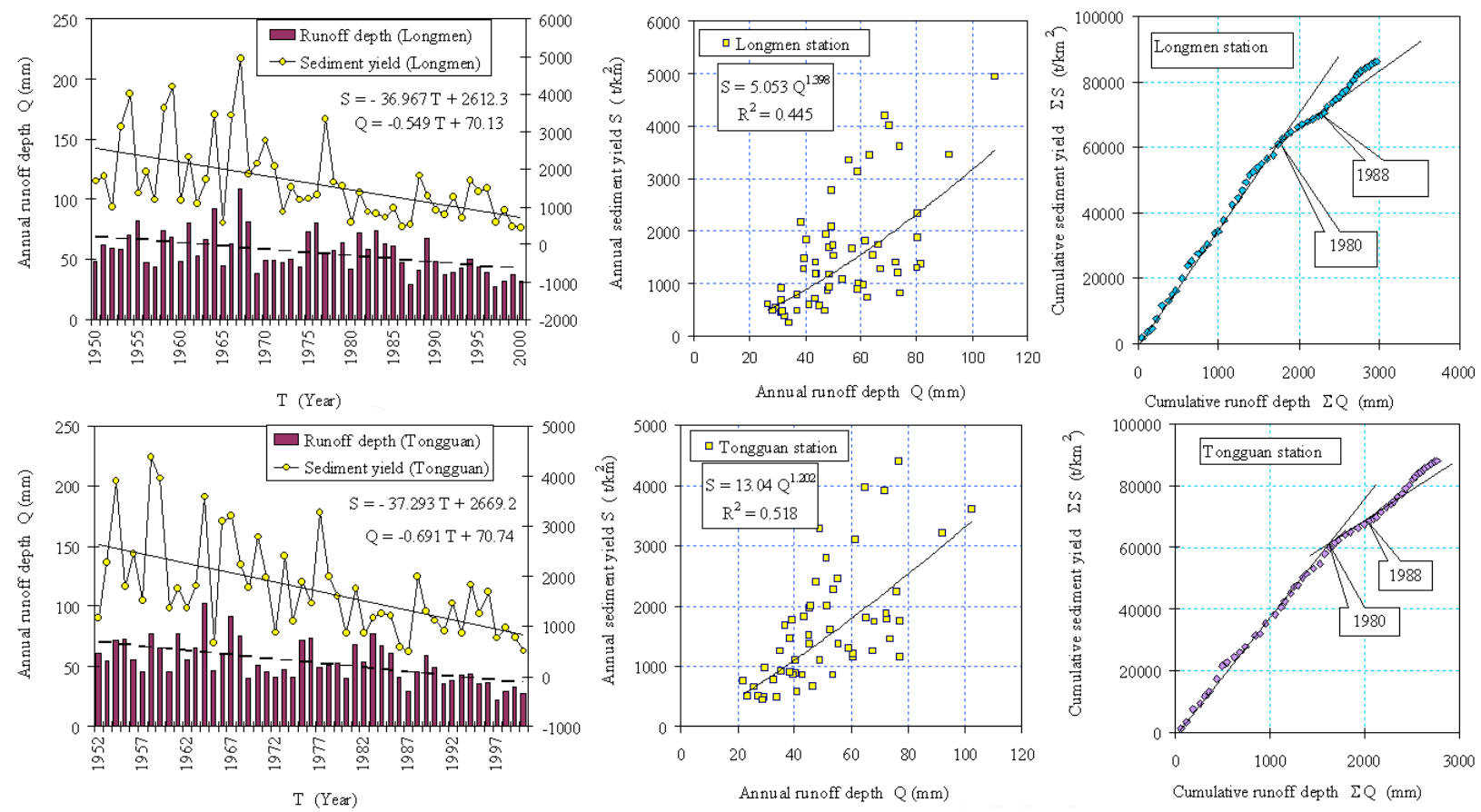

Figure 6. Changes in annual runoff depth and sediment yield of the middle reach of the Yellow River.

of the Toudaoguai station in 1998 is $1.75 \times 10^{9} \mathrm{~m}^{3}$ which accounts of $47 \%$ of total water transfer capacity. The relationship between annual sediment yield and annual runoff depth at the Toudaoguai station is strong.

\subsection{Changes in Runoff Depth and Sediment Yield in the Middle Reach}

Two studied gauging stations are located on the Middle Reach of the Yellow River: Longmen and Tongguan stations. As shown in Table 2 and Figure 6, both annual runoff depth and sediment yield of the sub-watersheds of the Yellow River at these 2 stations have a clearly downward trend with time. Results indicate that both the long-term and short term (in recent 10 years) annual runoff depth is much lower than those at the Tangnaihai and Lanzhou stations in the headwater region. The long-term average annual runoff depth at the Longmen and Tongguan stations is 53.68 and $51.29 \mathrm{~mm}$ respectively, and decreased to 32.47 and $29.79 \mathrm{~mm}$ respectively in recent 10 years. However, the annual sediment yield at these 2 stations on the Middle Reach is extremely high. The longterm average annual sediment yield at the Longmen and Tongguan stations is 1543.65 and $1631.39 \mathrm{t} / \mathrm{km}^{2}$ respectively, and decreased to 612.48 and $766.13 \mathrm{t} / \mathrm{km}^{2}$ respectively in recent 10 years. The decreased precipitation in the Middle Reach region of the Yellow River as discussed above and severe soil erosion from the Loess Plateau in this region (Sui et al., 2005) together with the increasing water consumption should be responsible for this specific feature of "low runoff depth but extreme high sediment yield" in the Middle Reach of the Yellow River.
As shown in Figure 6, a clearly low sediment yield at the Longmen and Tongguan stations on the Middle Reach experienced in 1980's. This low sediment yield along the Middle Reach in 1980's may be resulted from: a) increased water transfer capacity, and b) effects of the soil and water conservation programs in the Upper and Middle reaches of the Yellow River. It is observed that the knee-points on the cumulative annual sediment yield curves at gauging stations on the Upper Reach of the Yellow River didn't appear on the cumulative annual sediment yield curves at gauging stations on the Middle Reach of the Yellow River. The capability of self-regulation of a river is likely responsible for this phenomenon. As Figure 6 shown, a clear dependence of annual sediment yield on annual runoff depth at these 2 stations on the Middle Reach of the Yellow River can be identified.

\subsection{Changes in Runoff Depth and Sediment Yield in the Lower Reach}

Following 4 studied gauging stations are located on the Lower Reach of the Yellow River: Huayuankou, Gaocun, Aishan and Lijin stations. As shown in Table 2 and Figure 7, both the annual runoff depth and sediment yield of the subwatersheds of the Yellow River at these stations have a clearly downward trend, although annual precipitation depth at 3 studied climate stations in the Lower Reach region of the Yellow River has a tendency of slightly increase. Both long-term and short term annual runoff depth at gauging stations on the Lower Reach of the Yellow River is much less than those at the Tangnaihai and Lanzhou stations on the Upper Reach of the Yellow River. The long-term average annual sediment yield at 

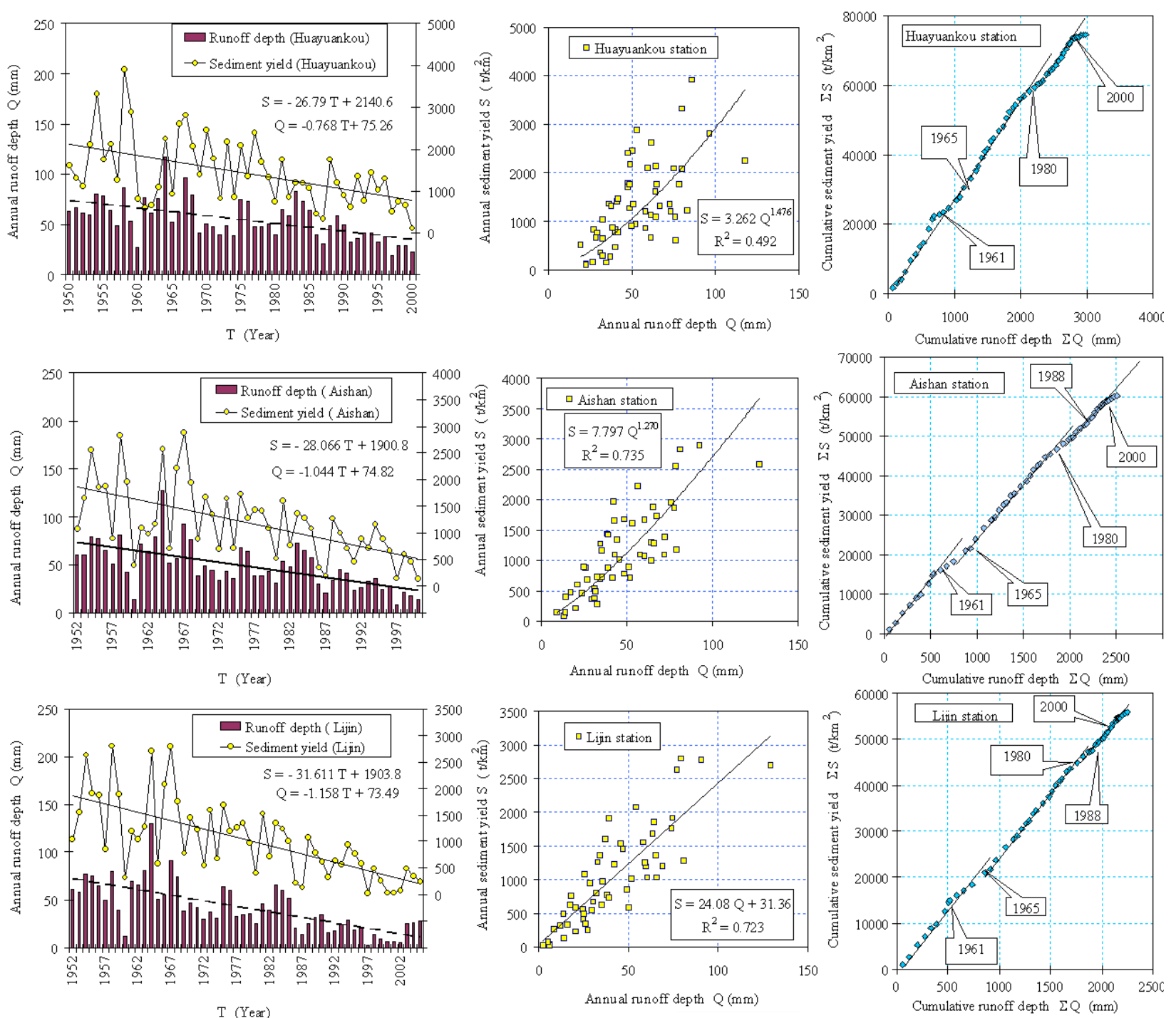

Figure 7. Changes in annual runoff depth and sediment yield of the lower reach of the Yellow River.

these 4 stations on the Lower Reach ranges from 1035 to 1330 $\mathrm{t} / \mathrm{km}^{2}$ which is still extremely high but less than those at 2 stations on the Middle Reach of the Yellow River. The average annual sediment yield at these 4 stations decreased significantly in recent 10 years, especially at the most downstream Lijin station. The long-term average annual runoff depth at these 4 stations ranges from 41.66 to $53.12 \mathrm{~mm}$ which is fairly low. In recent 10 years, the average annual runoff depth at these 4 stations ranges only from 14.41 to $29.35 \mathrm{~mm}$.

As the cumulative annual sediment yield curves shown in Figure 7, all gauging stations on the Lower Reach experienced a clearly decrease in sediment yield in 1961, 1980 and 2000 respectively. The Sanmenxia reservoir plays a very important role on the sediment yield in the Lower Reach. Before 1960, the Yellow River flew under a natural condition. As Figure 7 shown, the annual sediment yield was high and the annual runoff depth was low. Started in 1960, the Sanmenxia reservoir was in operation for water impoundment. As a result, the annual sediment yield at these 4 downstream gauging stations decreased dramatically. From 1965 to 1973, the operation modes of the Sanmenxia reservoir were modified for flood detention and sediment flushing. Therefore, both annual sediment yield and runoff depth at these 4 stations increased during this period. Since 1974, the operation modes of the Sanmenxia reservoir have been modified for "impoundment of clear water during low flow seasons and release of turbid water during flood periods”. Started in 1980, water consumption increased significantly due to booming economy along the Yellow River. Additionally, a lot of water and soil conservation projects in the Loess Plateau have been carried out. As a result, both annual sediment yield and runoff depth in the Lower Reach of the Yellow River decrease significantly after 1980 . The trend lines of both annual runoff depth and annual sediment yield at these 4 stations also reflect the influences of reservoir operations 
and increased water consumption in the Middle and Upper reaches of the Yellow River. As Figure 7 shown, the annual runoff depth at the most downstream Lijin station increased after 2002. This was resulted from the operation of the Xiaolangdi reservoir which is used to create high flow for dredging the channel of the Lower Reach of the Yellow River.

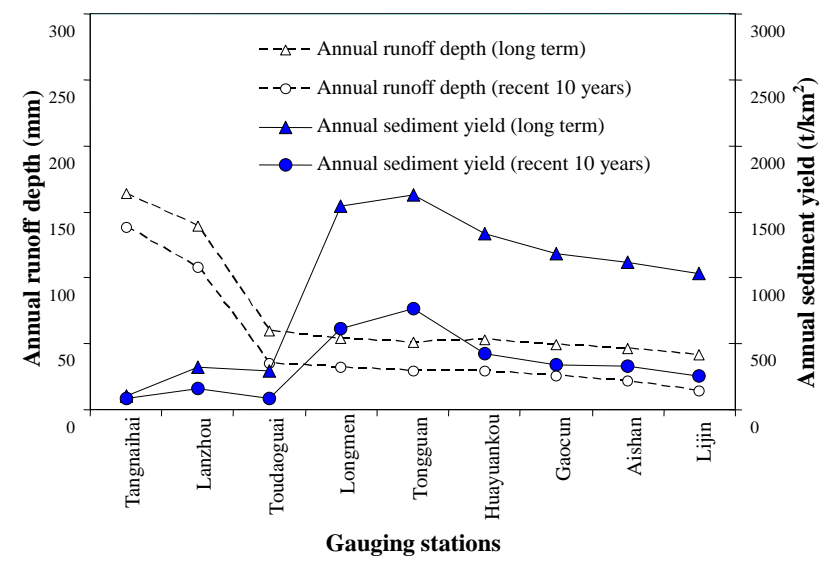

Figure 8. Changes in annual runoff depth and sediment yield along the Yellow River from upstream to downstream.

As shown in Figure 8, the average annual runoff depth at the Tangnaihai and Lanzhou stations in the headwater region is very high comparing to those at stations on the Middle and Lower reaches of the Yellow River. However, the annual sediment yield in the headwater region is very low. At the Toudaoguai station, which is the last station of the Upper Reach of the Yellow River, annual sediment yield is also fairly low comparing to those at stations on the Middle and Lower reaches of the Yellow River. The annual runoff depth at the Toudaoguai station is much lower than those at the Tangnaihai and Lanzhou stations in the headwater region of the Yellow River, but more than those at stations on the Middle and Lower reaches of the Yellow River. Overall, the average annual runoff depth (both long-term and short term) decreases quickly along the Upper Reach. Afterward, the average annual runoff depth decreases gradually along the Middle and Lower reaches. The annual sediment yield, however, is highest at the Longmen and Tongguan stations on the Middle Reach. In recent 10 years, the ratio of short term annual sediment yield to that of long- term decreased to about 30\% in the Lower Reach of the Yel- low River with a minimum ratio of $25 \%$ at the most down- stream Lijin station.

Figure 9 shows the relationship between annual sediment yield and runoff depth for all studied stations. Figure 10 shows the dependence of sediment concentration on discharge for all studied stations. It is observed that, for the same runoff depth or discharge, the sediment yield or sediment concentration of the Upper Reach of the Yellow River is much less than that in the Middle and Lower reaches. For the same runoff depth, the sediment flux of the Lower Reach is also much less than that in the Middle Reach. The extremely high sediment yield and sediment concentration occurred in the Middle Reach although the annual runoff depth or average discharge is fairly low.

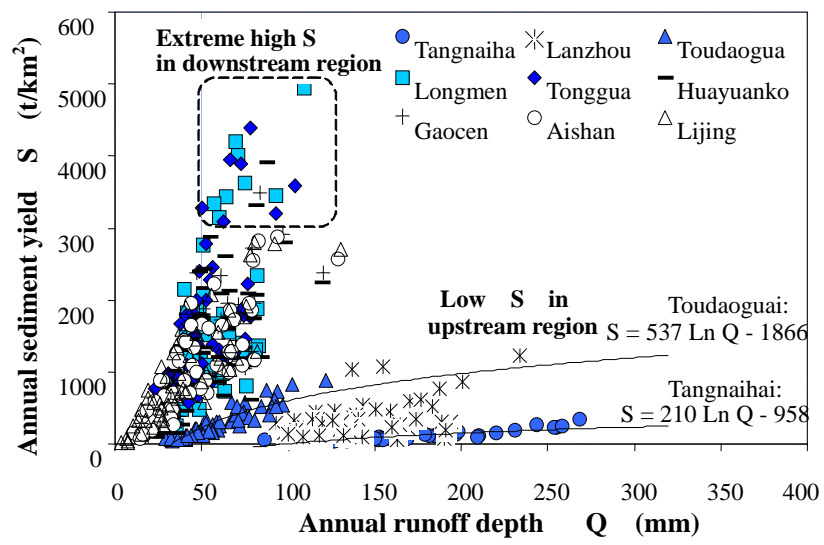

Figure 9. Dependence of annual sediment yield on annual runoff depth of the Yellow River.

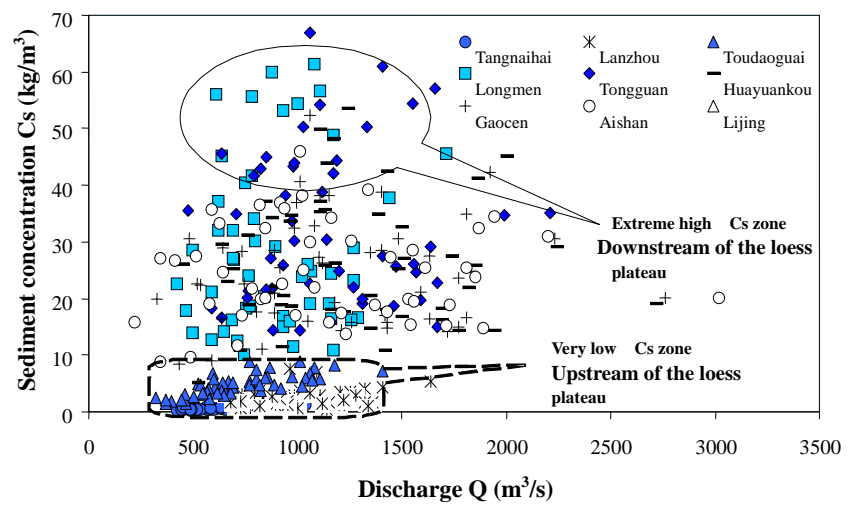

Figure 10. Dependence of sediment concentration on flow discharge of the Yellow River.

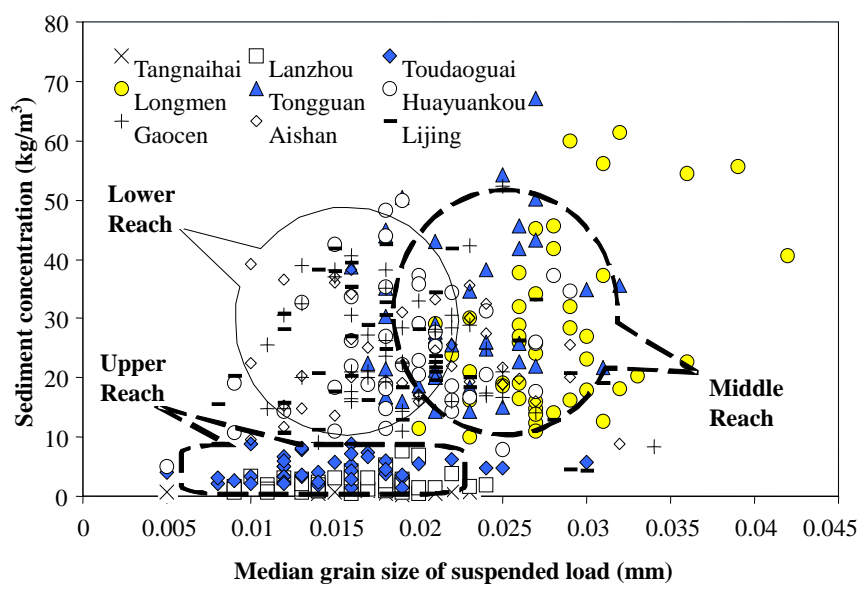

Figure 11. Dependence of sediment concentration on grain size of suspended load in the Yellow River. 
The grain size of suspended load also varies from upstream to downstream. As shown in Figure 11, the suspended load in the Upper Reach of the Yellow River seems finer than that in the Lower Reach. In the Middle Reach, the suspended load has the largest grain size. As Sui et al. (2005) claimed, local flash floods in summer between July and August result in a significant increase in discharge in some local branch rivers in the Loess Plateau such as the Huanfuchuan and Kuye branch rivers. The summer flash floods deliver huge amount of coarse sediment eroded from the poorly vegetated region in the Loess. Plateau to the Yellow River, and thus lead to the hyper-concentrated floods of the Yellow River during summer flood seasons.

\section{Conclusions}

In this paper, changes in annual runoff depth and sediment yield have been assessed by using long-term observation data at 9 gauging stations on the Yellow River and 12 climate stations in the Yellow River watershed in China. It is found that the sediment yield in the headwater region is fairly low although the annual runoff depth in the headwater region is very high. In the Middle Reach of the Yellow River, both annual runoff depth and sediment yield have a clearly downward trend with time. In the Lower Reach, both long-term and short term annual runoff depth is much lower than those in the headwater region.

The annual sediment yield in the Middle Reach is extremely high, with a long-term annual sediment yield of 1543.65 $\mathrm{t} / \mathrm{km}^{2}$ at the Longmen station and $1631.39 \mathrm{t} / \mathrm{km}^{2}$ at the Tongguan station. The average short-term sediment yield in recent 10 years at the Longmen station is 612.48 and $766.13 \mathrm{t} / \mathrm{km}^{2}$ at the Tongguan station. In the Lower Reach, both annual runoff depth and sediment yield have a clearly downward trend. Both long-term and short term runoff depth is much lower than those in the headwater region. However, the long-term average annual sediment yield in the Lower Reach varies from 1,035 to $1,330 \mathrm{t} / \mathrm{km}^{2}$ which is still extremely high but less than those at gauging stations on the Middle Reach. The average annual sediment yield decreased significantly in recent 10 years, especially for the most downstream Lijin station.

Impacts of human activities on the changes in runoff depth and sediment yield are noticeable. Since the headwater region has hardly been affected by human activities, such as through hydro-power development and soil conservation programs, no clear changes in runoff and sediment yield have been observed. In the Middle and Lower reaches, however, runoff depth and sediment yield have been dramatically influenced by human activities such as reservoirs installations, operation modes of reservoirs, increased water consumptions, and the water and soil conservation programs carried out in the Loess Plateau.

It is found, for the same discharge, the sediment transport of the Upper Reach of the Yellow River is much less than that in the Middle and Lower reaches of the Yellow River. For the same runoff depth, the sediment flux at gauging stations on the Lower Reach is also much less than that in the Middle Reach. The extremely high sediment yield occurred in the
Middle Reach, although the annual runoff depth is fairly low along the Middle Reach. Interestingly, the grain size of suspended load varies from upstream to downstream. The suspended load in the Upper Reach of the Yellow River is finer than that in the Lower Reach of the Yellow River. In the Middle Reach of the Yellow River, due to the impact of the Loess Plateau, the suspended load has the largest grain size.

Acknowledgments. The paper represents a contribution to the UNESCO International Sediment Initiative (ISI).

\section{References}

Gu, W.S. (1994). On the reduction of water and sediment yield of the Yellow River in late years, International Journal of Sediment Research, 9(1), 1-12.

Gu, W.S. (2002). Report on changes in water and sediment loads of the Yellow River, Researches on Changes in Water and Sediment Loads of the Yellow River, Wang G. and Fan Z. eds. Zhengzhou, Yellow River Conservancy Press, pp. 1-45.

Liu, C., Sui, J. and Wang, Z.Y. (2008). Sediment load reduction in Chinese rivers, International Journal of Sediment Research, 23 (1), 44-55.

Lu, J.F. and Huang, X.H. (2003). Response of sediment yield to basin characteristics in the Middle Yellow River basin, International Journal of Sediment Research, 9(2), 18.

Ludwig, W., Probst, J.L. and Kempe, S. (1996). Predicting the oceanic input of organic carbon by continental erosion, Global Biogeochem. Cycles, 10(1), 23-41.

Ministry of Water Resources of China (MWR). (2001). China Gazette of River Sedimentation 2000, China Water Power Press, Beijing, China.

Ministry of Water Resources of China (MWR). (2002). China Gazette of River Sedimentation 2001, China Water Power Press, Beijing, China.

Ministry of Water Resources of China (MWR). (2003). China Gazette of River Sedimentation 2002, China Water Power Press, Beijing, China.

Ministry of Water Resources of China (MWR). (2004). China Gazette of River Sedimentation 2003, China Water Power Press, Beijing, China.

Ministry of Water Resources of China (MWR). (2005). China Gazette of River Sedimentation 2004, China Water Power Press, Beijing, China.

Ministry of Water Resources of China (MWR). (2006). China Gazette of River Sedimentation 2005, China Water Power Press, Beijing, China.

Sui, J., Jackson, P., Liu, C., Fang, D. and Wang J. (2005). Characteristics of sediment transport along a river reach with a reservoir, International Journal of Sediment Research, 20(2), 89-102.

Sui, J., Wang, D. and Karney, B. (2000). Suspended Sediment concentration and deformation of riverbed in a frazil jammed river reach, Can. J. Civ. Eng., 27(6), 1120-1129, doi:10.1139/cjce-27-61120.

Wang, X.D. and Wang Z.Y. (1999). Effect of land use on runoff and sediment yield, International Journal of Sediment Research, 14(4), 59-66

Wang, Z.Y. and Dittrich, A. (1999). Effect of particle's shape on incipient motion of sediment, International Journal of Sediment Research, 14(4), 179-186.

Wang, Z.Y. and Wu, Y.S. (2001). Sediment-removing capacity and river motion dynamics, International Journal of Sediment Research, 16(2), 105-115.

Walling, D.E. (2005). Recent changes in the suspended sediment 
transport modulus of the world's rivers: the impact of environmental Change, the 3rd ISI steering Committee Meeting, 28-30 April, 2005, Vienna, Austria.

Walling, D.E. (2006). Human impact on land-ocean sediment transfer by the world's rivers, Geomorphology, 79(3), 192-216, doi: 10.101 6/j.geomorph.2006.06.019.

Walling, D.E. and Fang, D. (2003). Recent trends in the suspended sediment load of the world, Global Planet. Change, 39(1-2), 111126, doi:10.1016/S0921-8181(03)00020-1.

Xu, J.X. (2003). Sedimentation rates in the lower Yellow River over the past 2300 years as influenced by human activities and climate change, Hydrological Process, 17(16), 3359-3371, doi:10.1002/hy p.1392.
Xu, Z. and Zhang, N. (2006). Long-term trend of precipitation in the Yellow River basin during the past 50 years, Geographical Research, 25 (1), 27-34.

Ye, B, Li, C., Yang, D., Ding, Y. and Shen, Y. (2004). Variation trend of precipitation and its impact on water resources in China during last 50 years I): Annual variation, Glaciology and Geocryology, 26, 587-594.

Yellow River Conservation Committee (YRCC), 1999-2006. Gazette of the Yellow River Water Resources (http://www.yellowriver.gov. cn/other/hhgb/)

Wang, Y.Z., Kang, L.L. and Wang, G.Q. (2004). Precipitation changes in the upper Yellow River reaches and its influence on the runoff for nearly 50 years, Yellow River, 26(2), 5-7. 